\title{
Differential Activation of Target Cellular Promoters by p53 Mutants with Impaired Apoptotic Function
}

\author{
ROBERT L. LUDWIG, STEWART BATES, AND KAREN H. VOUSDEN* \\ ABL Basic Research Program, National Cancer Institute-Frederick Cancer Research and \\ Development Center, Frederick, Maryland 21702-1201
}

Received 12 March 1996/Returned for modification 14 May 1996/Accepted 3 June 1996

\begin{abstract}
The p53 tumor suppressor protein is a sequence-specific transcriptional activator, a function which contributes to cell cycle arrest and apoptosis induced by p53 in appropriate cell types. Analysis of a series of p53 point mutants has revealed the potential for selective loss of the ability to transactivate some, but not all, cellular p53-responsive promoters. p53 175P and p53 181L are tumor-derived p53 point mutants which were previously characterized as transcriptionally active. Both mutants retained the ability to activate expression of the cyclin-dependent kinase inhibitor $\mathrm{p21}^{\text {cip1/wafl }}$, and this activity correlated with the ability to induce a $\mathrm{G}_{1}$ cell cycle arrest. However, an extension of this survey to include other p53 targets showed that p53 175P was defective in the activation of p53-responsive sequences derived from the bax promoter and the insulin-like growth factor-binding protein 3 gene (IGF-BP3) promoter, while p53 181L showed loss of the ability to activate a promoter containing IGF-BP3 box B sequences. Failure to activate transcription was also reflected in the reduced ability of the mutants to bind the p53-responsive DNA sequences present in these promoters. These specific defects in transcriptional activation correlated with the impaired apoptotic function displayed by these mutants, and the results suggest that activation of cell cycle arrest genes by p53 can be separated from activation of genes with a role in mediating the p53 apoptotic response. The cellular response to p53 activation may therefore depend, at least in part, on which group of p53-responsive genes become transcriptionally activated.
\end{abstract}

p53 is the most commonly mutated tumor suppressor protein in many different types of human cancer (31). Although there is no clear essential role for p53 during normal development (19), lack of functional p53 is associated with an increased risk of tumor development, both in mice with homozygous p53 deletions $(19,33)$ and in humans carrying a heterozygous p53 mutations $(39,48)$. This function of p53 is reflected in vitro, in that expression of wild-type p53 can suppress the growth of human tumor cells in culture $(3,18)$. Two activities of p53 which contribute to the inhibition of cell growth have been described: the ability to activate a cell cycle arrest and the induction of programmed cell death (apoptosis) (reviewed in reference 5). Although the wild-type p53 protein can activate either pathway, depending on cell type and environment, analysis of p53 mutants has indicated that the two pathways represent distinct functions of p53. Thus, a tumorderived p53 point mutant shows specific loss of apoptotic activity despite retaining wild-type cell cycle arrest function (44), whereas other p53 mutants, which are unable to induce a cell cycle arrest, remain competent for the induction of apoptosis in some cell types (29). Although the mechanisms underlying the choice of cellular response is not clear, several studies have shown that the induction of apoptosis or cell cycle arrest can be governed by the presence or absence of survival factors $(1,9$, $11,25,56)$.

Several functions of p53 which might mediate cell cycle arrest and apoptosis, including the ability to regulate transcription and DNA replication, have been described. In most cells, sequence-specific transcriptional activation by p53 is closely

\footnotetext{
* Corresponding author. Mailing address: ABL Basic Research Program, NCI-FCRDC, Building 560, Room 22-96, P.O. Box B, Frederick, MD 21702-1201. Phone: (301) 846-1726. Fax: (301) 8466666. Electronic mail address: vousden@ncifcrf.gov.
}

correlated with suppression of cell growth and induction of cell cycle arrest $(14,43)$. This process is mediated in part by $\mathrm{p} 53$ dependent activation of expression of p21 $1^{\text {cip1/wafl }}(21)$, an inhibitor of the cyclin-dependent kinases which are necessary for progression through the cell cycle $(20,54)$. At least one of the consequences of $\mathrm{p} 21^{\text {cip1/wafl }}$ activation is the inability to phosphorylate another tumor suppressor protein, $\mathrm{pRB}$, resulting in persistence of the pRB-mediated $\mathrm{G}_{1}$ block to cell cycle progression. The importance of this pathway is illustrated by the ability of viral proteins which interfere with $\mathrm{pRB}$ function, such as human papillomavirus E7, to overcome a p53-induced $\mathrm{G}_{1}$ cell cycle arrest $(16,30,46)$. The contribution of sequencespecific transcriptional activation to the induction of apoptosis is less clear. Although transcriptional activity appears to contribute to the induction of apoptosis in some cells $(45,55)$, other studies have demonstrated p53-dependent cell death in the absence of transcriptional activation $(8,29,51)$. We have proposed previously that transcriptionally dependent and transcriptionally independent functions of p53 contribute to cell death, the importance of each of these functions depending on cell type. Several p53-inducible genes with a clear potential for contribution to apoptosis, such as bax and fas/apo1, have been described (40-42), although the importance of activation of these genes is not certain. Indeed, the apparently normal induction of p53-dependent apoptosis in bax-deficient thymocytes (35) suggests that this is not an essential mediator of the p53 apoptotic signal in all cells.

Analysis of the transcriptional activity of p53 mutants by using synthetic consensus sequence promoters has shown that mutations at amino acid residue 273 , a site frequently mutated in human tumors, renders p53 incapable of activating most synthetic and natural promoters but does not abolish the ability to activate a synthetic consensus binding site promoter, p53CON (10). Similarly, differential sequence-specific DNA 
A

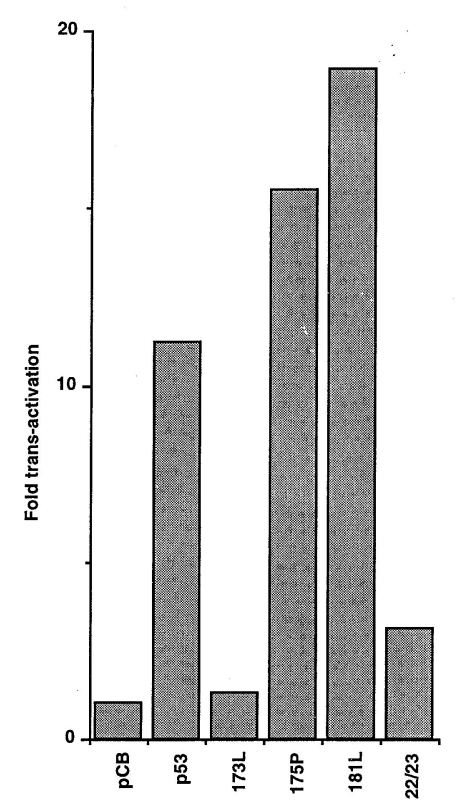

B

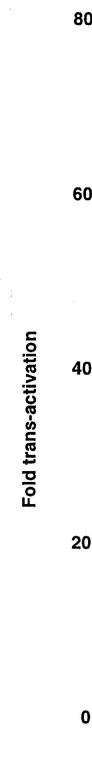

C

¿ 高

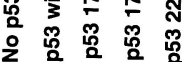

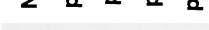

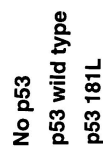

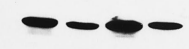

$\longrightarrow \sim$ p53

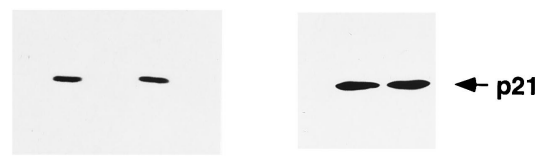

FIG. 1. (A and B) Transcriptional activation by wild-type p53 and the indicated mutants of the p53-responsive p21 $1^{c i p 1 / w a f 1}$ promoter plasmid pWWP-luc. Assays were carried out following transfection of $50 \mathrm{ng}$ of plasmid DNA into Saos-2 cells (A) or $500 \mathrm{ng}$ of plasmid DNA into H358 cells (B). (C) Western blot analysis of Saos-2 cells transiently transfected with the indicated p53 plasmid and probed with p53- and p21 $1^{\text {cip } 1 / \text { wafl }}$-specific monoclonal antibodies.

binding activity has been described for several p53 mutants (49). These studies suggested that not all p53-responsive cell promoters are equally sensitive to different p53 mutants. We have previously described a p53 mutant which retains both sequence-specific transcriptional activity and the ability to induce cell cycle arrest but nevertheless is clearly defective for the induction of apoptosis (44). We suggested that this mutant may be defective in the transcriptionally independent apoptotic function of p53 or show specific loss in the transcriptional activation of apoptotic target genes despite retaining the ability to induce expression of proteins like p21 $1^{\text {cip } 1 / \text { waf1 }}$ which con- tributed to the cell cycle arrest. In support of the latter suggestion, we have now analyzed the abilities of several p53 point mutants to activate a series of cell-derived p53-responsive promoters and show that some of the mutants show differential activities. Two mutants which retain wild-type cell cycle arrest functions but show impaired apoptotic function activate the p $21^{\text {cip1/waf1 }}$ promoter at least as efficiently as the wild-type protein, but each shows defects in the activation of promoters containing sequences derived from either the bax or insulinlike growth factor (IGF)-binding protein 3 gene (IGF-BP3) promoter.

\section{A. Bax}

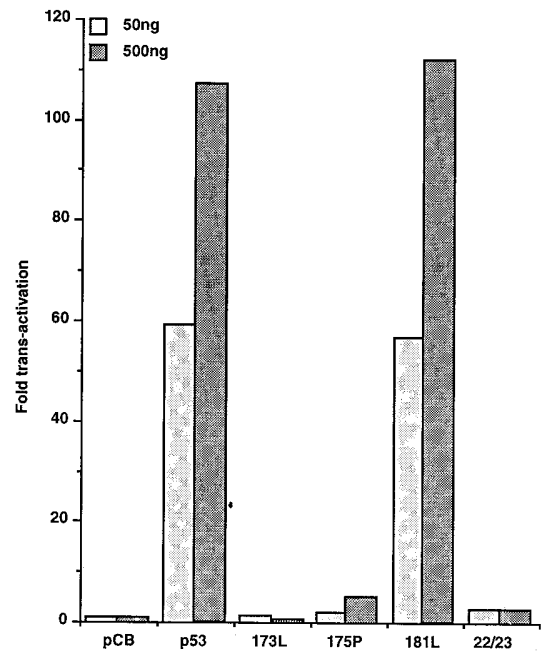

\section{B. IGF-BP3 box A}

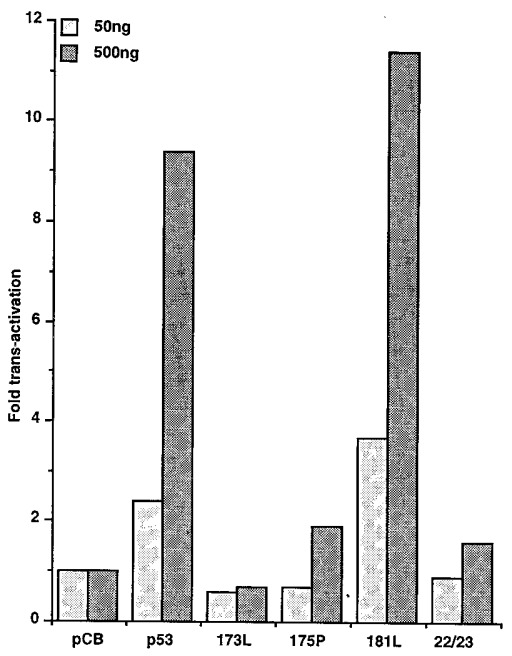

\section{IGF-BP3 box B}

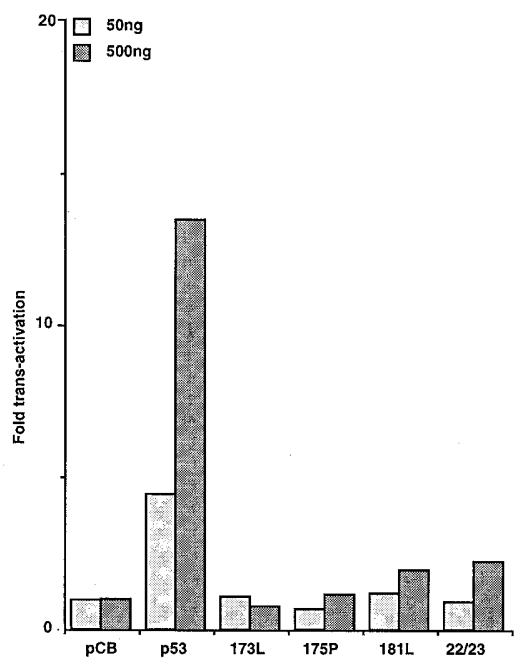

FIG. 2. Transcriptional activation by wild-type p53 and the indicated mutants of the p53-responsive promoter plasmids Bax-Luc (A), IGF-BP3 boxA-Luc (B), and IGF-BP3 (2)boxB-Luc (C) in Saos-2 cells. In each case, transcriptional activity following transfection of either 50 or 500 ng of plasmid DNA is shown. 
A. Bax

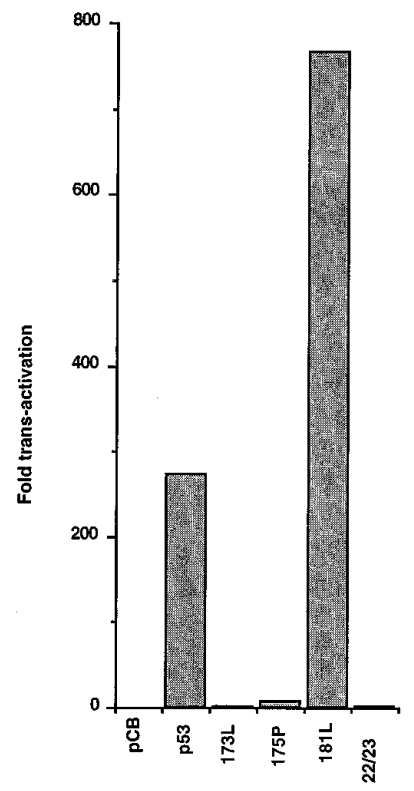

\section{B. IGF-BP3 box B}

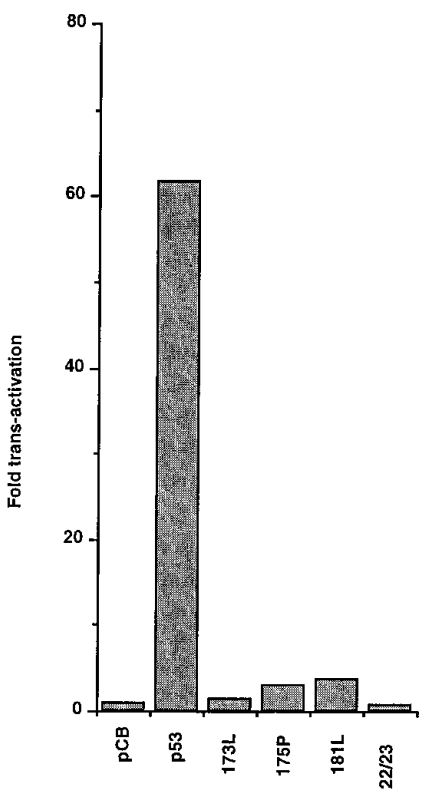

FIG. 3. Transcriptional activation by wild-type $\mathrm{p} 53$ and the indicated mutants of the p53-responsive promoter plasmids Bax-Luc (A) and IGF-BP3 (2)boxBLuc (B) in H358 cells. In each case, transcriptional activity following transfection of $500 \mathrm{ng}$ of plasmid DNA is shown.

\section{MATERIALS AND METHODS}

Plasmids. p53 sequences were placed in plasmids under the control of the cytomegalovirus early promoter as described previously $(38,44)$. Transcriptional activation by $\mathrm{p} 53$ was assayed by using reporter constructs in which expression of the luciferase gene was regulated by 553 -responsive promoters. These reporters contained $\mathrm{p} 53$-responsive sequences from cellular promoters controlling expression of human $\mathrm{p} 21^{\text {cipl/wafl }}$ in pWWP-luc (21), human bax in Bax-Luc, derived from plasmid Bax-CAT (41), or human IGF-BP3 in plasmids IGF-BP3 boxA-Luc and IGF-BP3 (2)boxB-Luc (7). Where appropriate, transfection efficiency was monitored by using $\mathrm{pJ} 4 \Omega \beta \mathrm{gal}$, a plasmid in which expression of the $\beta$-galactosidase gene is under the control of the Moloney murine leukemia virus long terminal repeat (12). Bax sequences were expressed from the CMV promoter as either full-length protein or protein epitope tagged at the $\mathrm{N}$ terminus for recognition by the antibody DO-1 (50).

Cell culture and transfection. p53-null human tumor cell lines Saos-2 and H358 were maintained in Dulbecco modified Eagle medium supplemented with

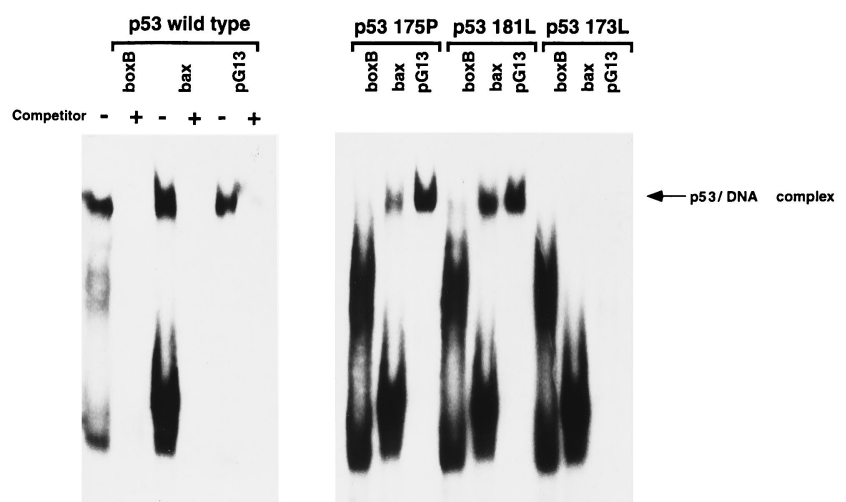

FIG. 4. DNA binding activities of in vitro-translated p53 proteins following incubation with the anti-p53 antibody PAb421. Oligonucleotides containing the p53 binding sequences from the pG13, bax, and IGF-BP3 box B promoters were used as indicated. Specificity of the shifts is demonstrated by the addition of unlabeled competitor p53 binding-site oligonucleotide.

$10 \%$ fetal calf serum. For transient transfections, $3 \times 10^{5}$ to $8 \times 10^{5}$ cells were seeded in a 100 -mm-diameter petri dish and transfected the following day, using calcium phosphate coprecipitation. Cells were transfected with $50 \mathrm{ng}$ to $10 \mu \mathrm{g}$ of he indicated p53 plasmid or empty vector control and $5 \mu \mathrm{g}$ of each reporter construct. Cells were harvested after 24 to $72 \mathrm{~h}$ and prepared for flow cytometry, luciferase, and $\beta$-galactosidase assays and Western blotting (immunoblotting).

Transcriptional activity and protein analysis. Cell lysates were prepared $24 \mathrm{~h}$ posttransfection and analyzed for luciferase and $\beta$-galactosidase as previously described (37). For Western blotting, equal amounts of lysates were subjected to polyacrylamide gel electrophoresis, and following transfer to nitrocellulose filters, the proteins were detected with the p53-specific monoclonal antibody PAb1801 (4) or the p21 $1^{\text {cip1/wafl }}$-specific monoclonal antibody SX118 (23).

DNA binding. The DNA binding activities of in vitro-translated p53 proteins were analyzed by electrophoretic mobility shift assay as previously described (13). p53 proteins were tested for the ability to bind an oligonucleotide encoding two p53 consensus binding sites (pG13) (22), p53 binding sequences from the bax promoter (41), the IGF-BP3 box B sequence (7), or the p21 $1^{\text {cip I/wafl }}$ promoter (21). The in vitro p53 proteins were activated for DNA binding by incubation with the p53 monoclonal antibody PAb421 as previously described (32), and competition for the specific binding was carried out by adding a 50 - to 100 -fold excess of unlabeled oligonucleotide with the antibody.

Flow cytometry. Total populations of transfected cells, including floating and adherent cells, were harvested 24 to $72 \mathrm{~h}$ posttransfection, fixed, and stained for p53 by using PAb1801 and for DNA content by using propidium iodide as previously described (44). Samples were analyzed in a cell sorter (FACScalibur; Becton Dickinson), and cells were measured for their fluorescein isothiocyanate (FITC) fluorescence intensity (green channel) and propidium iodide fluorescence (red channel). Total populations were gated to remove doublets and very small debris. Background levels of FITC fluorescence were established by using vector-only-transfected cells, and cells in p53-transfected populations with high FITC fluorescence were gated and analyzed as done for the p53-expressing population. Cell cycle analysis of p53-expressing and -nonexpressing cells from each transfection was performed with the CellQuest analysis software (Becton Dickinson), and apoptosis induced by each p53 protein was expressed as the percentage of the level for cells with a sub- $\mathrm{G}_{1}$ DNA content in excess of that seen in the untransfected population, which ranged from 2 to $4 \%$.

\section{RESULTS}

Differential transcriptional activities of tumor-derived p53 point mutants. A series of previously described $\mathrm{p} 53$ point mutants was chosen to analyze the relationship between cell cycle arrest, apoptosis, and sequence-specific transcriptional activation induced by the tumor suppressor protein in more detail. Three of the point mutants, p53 181L, p53 175P, and p53 173L, were identified in metastases from cervical carcinoma; each carries a single amino acid substitution within the conserved central DNA binding domain of p53, in the region termed conserved box III (47). Also included in this study was p53 $22 / 23$, a targeted mutant with substitutions within the N-terminal transactivation domain of the protein (38).

Sequence-specific transcriptional activity of each of these p53 mutants has been described; p53 181L and p53 175P both retain the ability to activate transcription from the synthetic p53 promoter pG13 and several p53-responsive cellular promoters such as the $\mathrm{p} 21^{\text {cip1/waf1 }}$ promoter and the $m d m 2$ promoter, while p53 173L and p53 22/23 are both defective for transcriptional activation $(14,15,38,45)$. Analysis of the mutants for the ability to activate transcription from the $\mathrm{p} 21^{\text {cip1/waf1 }}$ promoter in two p53-null human tumor cell lines, Saos- 2 and H358, confirmed that the transcriptional activities of the p53 175P and p53 181L mutants were as efficient as that exhibited by the wild-type protein. Both p53 173L and p53 $22 / 23$ were essentially unable to activate expression from these promoters, as expected (Fig. 1A and B). Levels of expression of endogenous $\mathrm{p} 21^{\text {cip } 1 / \text { waf } 1}$ in the transiently transfected cells were elevated only in cells expressing wild-type p53, p53 175P, and p53 181L (Fig. 1C), confirming that the activation of the isolated $\mathrm{p} 21^{\text {cip } 1 / \text { wafi }}$ promoter in the reporter construct was an accurate reflection of the activation of the promoter in the normal genomic context and further supporting the retention of transcriptional activity for these mutants.

Although activation of $\mathrm{p} 21^{\text {cip } 1 / \text { waf } 1}$ appears to play an impor- 
A. Saos-2
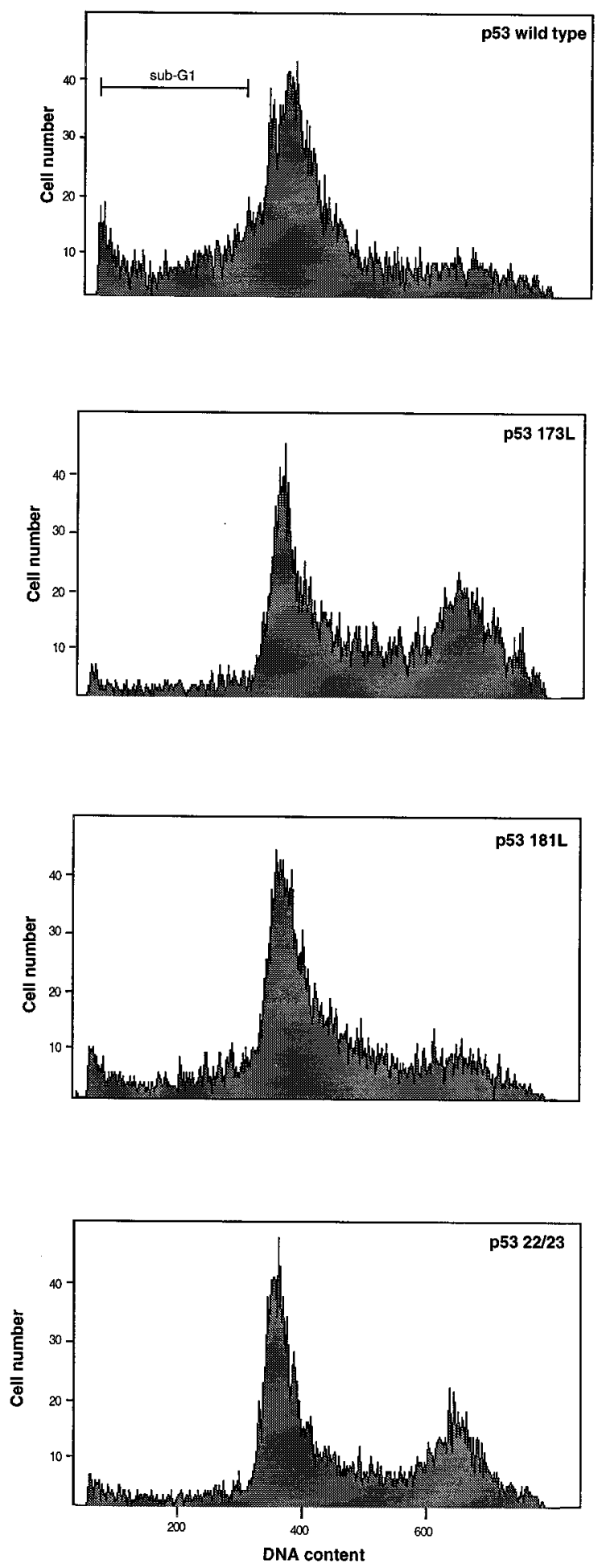

B. $\mathrm{H} 358$
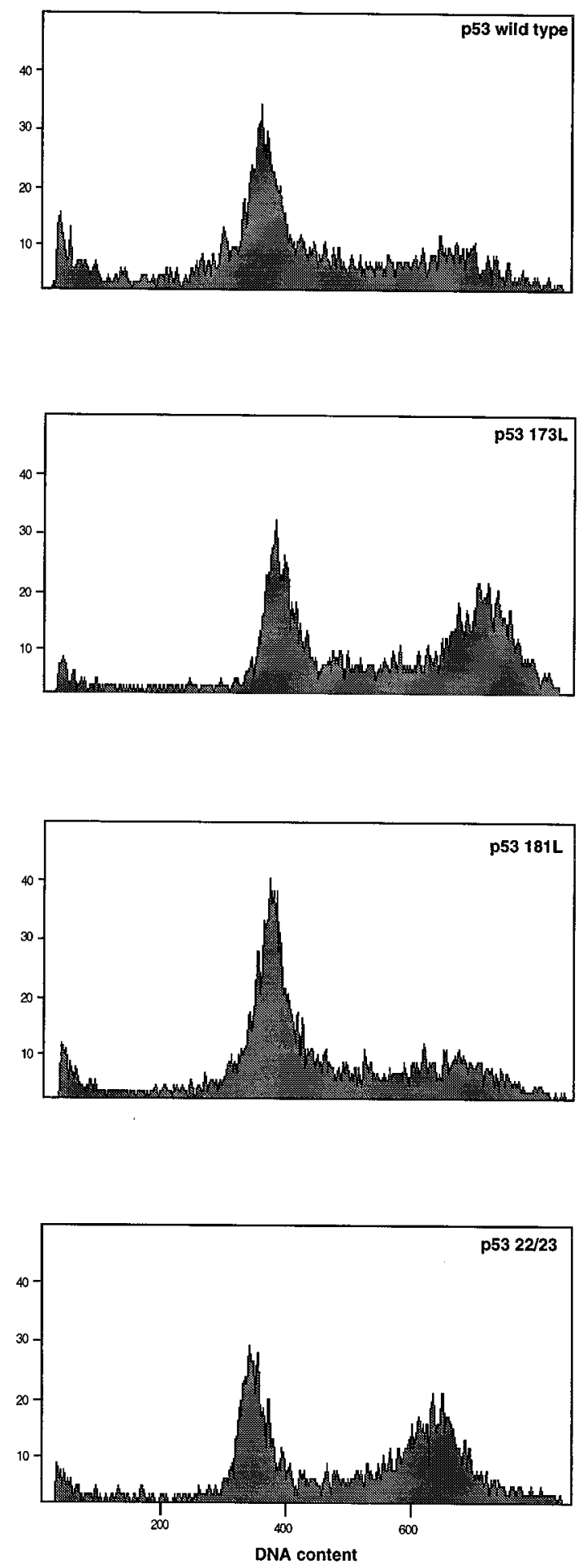

FIG. 5. Flow cytometric analyses of Saos-2 (A) and H358 (B) cells expressing wild-type p53 or the indicated mutants. Cell cycle arrest is indicated by an increase in the $G_{1}$ population accompanied by a decrease in the number of cells in the $S$ and $G_{2} / M$ compartments. Apoptosis is measured by the accumulation of cells with a sub-G $\mathrm{G}_{1}$ DNA content. 


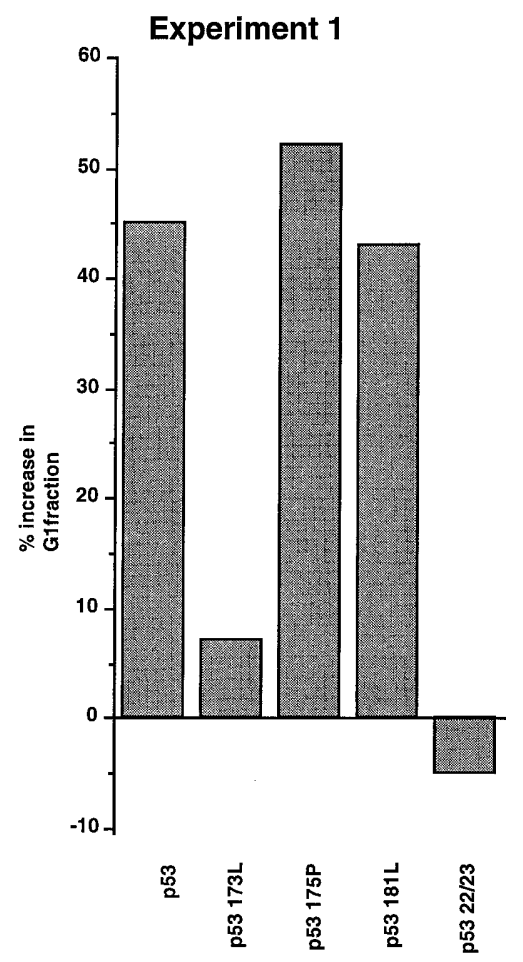

Experiment 2

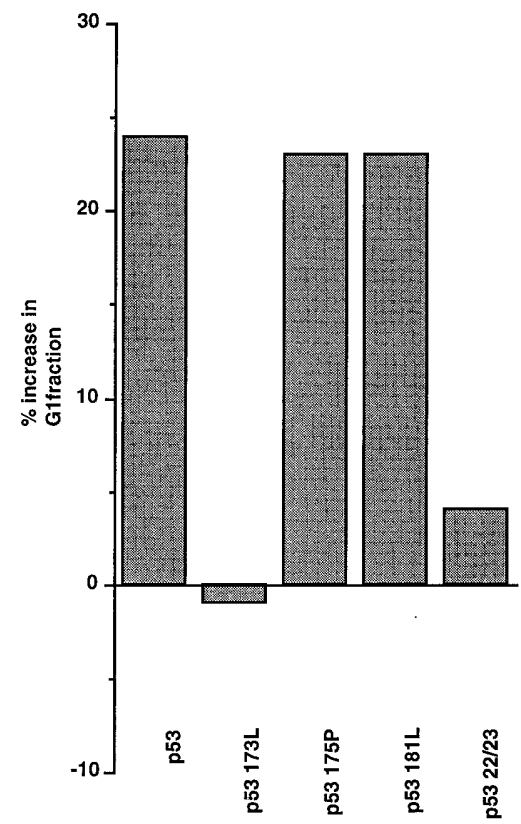

FIG. 6. Cell cycle arrest of Saos-2 cells expressing wild-type p53 or the indicated mutants in two independent experiments. The graphs show the percentage increase in $\mathrm{G}_{1}$ in the p53-expressing cycling cells compared with the population of cells not expressing p53.

tant role in mediating the cell cycle arrest function of p53, it is clear that enhanced expression of this cellular target cannot account for all of the biological activity of p53; in particular, activation of apoptosis does not appear to be the consequence of enhanced p21 $1^{\text {cip1/wafl }}$ expression in most cells $(6,17,34,36)$. We therefore examined the p53 mutants with respect to the activation of other p53-responsive cellular promoters. Analysis of the bax promoter (41) and two independent p53-responsive
A

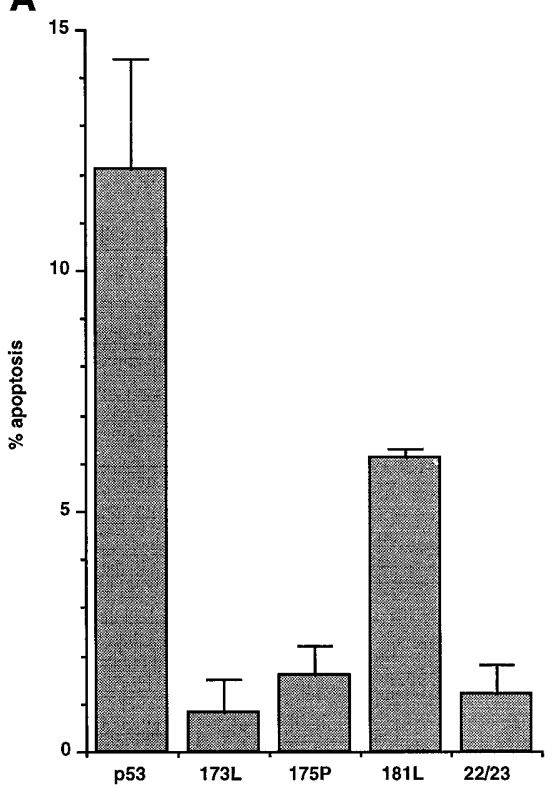

B

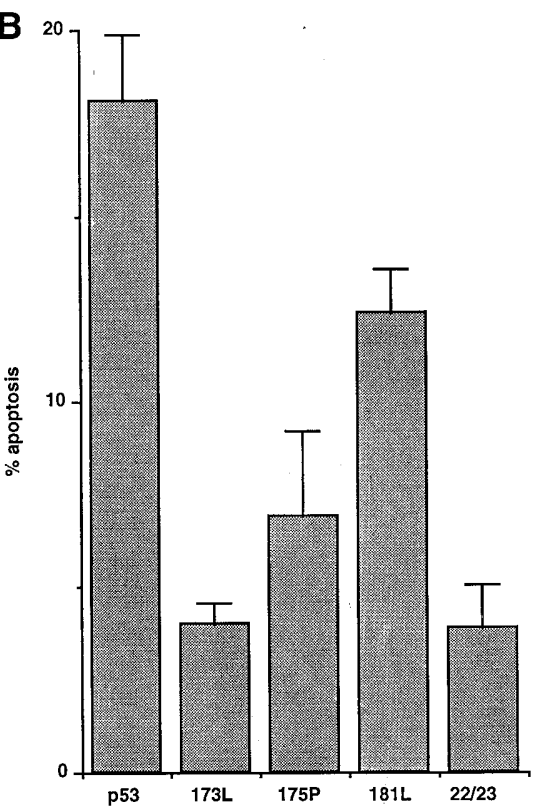

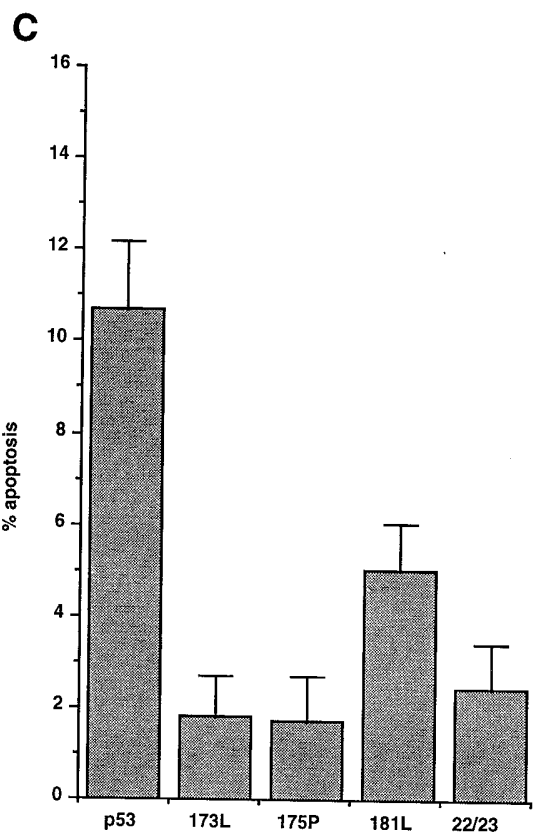

FIG. 7. Apoptosis in cells expressing wild-type $\mathrm{p} 53$ or the indicated mutants, measured by the percentage of cells with a sub-G $\mathrm{G}_{1} \mathrm{DNA}_{\mathrm{N}}$ content. Each graph represents the means of three to six independent experiments and shows the percentage of apoptotic cells in Saos-2 cells 24 (A) and 72 (B) h posttransfection and in H358 cells $72 \mathrm{~h}$ posttransfection $(\mathrm{C})$. 
TABLE 1. Summary of activities of p53 mutants $^{a}$

\begin{tabular}{|c|c|c|c|c|c|c|c|c|}
\hline \multirow{2}{*}{$\begin{array}{c}\text { p53 } \\
\text { protein }\end{array}$} & \multicolumn{3}{|c|}{ Promoter activation } & \multicolumn{3}{|c|}{ DNA binding } & \multirow{2}{*}{$\begin{array}{c}\text { Growth } \\
\text { arrest }\end{array}$} & \multirow[b]{2}{*}{ Apoptosis } \\
\hline & $\mathrm{p} 21$ & $\operatorname{bax}$ & $\begin{array}{c}\text { IGF-BP3 } \\
\text { box B }\end{array}$ & $\mathrm{p} 21$ & bax & $\begin{array}{c}\text { IGF-BP3 } \\
\text { box B }\end{array}$ & & \\
\hline Wild type & + & + & + & + & + & + & + & + \\
\hline $173 \mathrm{~L}$ & - & - & - & - & - & - & - & - \\
\hline $175 \mathrm{P}$ & + & - & - & + & $+1-$ & - & + & - \\
\hline $181 \mathrm{~L}$ & + & + & - & + & + & - & + & $+/-$ \\
\hline $22 / 23$ & - & - & - & & & & - & - \\
\hline
\end{tabular}

elements from the IGF-BP3 promoter (box A and box B) (7) in Saos- 2 cells revealed differential activities for the apparently transcriptionally active p53 mutants (Fig. 2). Despite retaining essentially wild-type ability to activate the $\mathrm{p} 21^{\text {cip1/wafl }}$ promoter, p53 175P failed to activate transcription from the bax promoter or either of the IGF-BP3 promoters, behaving instead like the transcriptionally inactive p53 173L and p53 22/23 mutants. p53 181L retained the ability to transcriptionally activate the bax promoter and IGF-BP3 box A promoter but was also unable to activate IGF-BP3 box B. The differential transcriptional activities of these mutants were confirmed in $\mathrm{H} 358$ cells: p53 175P was unable to activate transcription from the bax or IGF-BP3 box B promoter, and p53 181L retained activity against the bax promoter but not the IGF-BP3 box B promoter (Fig. 3). Equivalent expression of the $\mathrm{p} 53$ proteins in these assays was confirmed by Western blotting (data not shown).

DNA binding. To determine whether the specific loss of transcriptional activity shown by the p53 175P and p53 181L mutants was the result of an impaired ability to bind to the p53 binding sites within these promoters, in vitro-translated p53 proteins were analyzed in band shift assays. p53 binding-site oligonucleotides were chosen to represent a promoter which was efficiently transcriptionally activated by wild-type p53, p53 175P, and p53 181L (pG13), a promoter which was activated by wild-type p53 and p53 181L but not p53 175P (bax), and a promoter which was activated only by the wild-type protein (IGF-BP3 box B). Oligonucleotides containing p53 bindingsite sequences derived from the $\mathrm{p} 21^{\text {cip } 1 / \text { wafl }}$ promoter were also tested and found to give results identical to those obtained with the pG13 sequences (data not shown). p53 173L, which fails to transcriptionally activate any of the promoters containing these binding sites, was included as a control, and the equivalent translation of each of the $\mathrm{p} 53$ proteins was confirmed by Western blotting (data not shown). The wild-type p53 protein bound all three oligonucleotides containing previously described p53 binding sites efficiently, and this activity was abrogated by the addition of excess unlabeled oligonucleotide (Fig. 4). The transcriptionally inactive mutant p53 173L failed to bind any of the oligonucleotides, consistent with complete loss of DNA binding activity. The faster-migrating retarded bands seen with the box B and bax oligonucleotides were not specific to p53, since they were also seen in assays using unprogrammed rabbit reticulocyte lysate (data not shown), although results of the competition assay suggest that they represent a specific DNA binding activity present in the lysate. p53 175P and p53 181L clearly retained efficient ability to bind the pG13 oligonucleotide (consistent with their ability to transcriptionally activate the pG13 promoter), and both mutants showed complete loss of binding to the IGF-BP3 box B oligonucleotide (consistent with their inability to activate this promoter). Although both mutants retained some ability to interact with the bax oligonucleotide, p53 175P showed a much weaker binding activity, correlating with the inability of this mutant to activate the bax promoter in cells.

Apoptotic and cell cycle arrest activities of the p53 mutants. It is clear that the apoptotic and cell cycle arrest functions of p53 are dependent on cell type and environment; for example, previous studies have shown that the p53 22/23 mutant retains efficient apoptotic function in human HeLa cells (29) while being entirely defective for this activity in E1A-transformed rodent cells (45). We have previously described the apoptotic and cell cycle arrest activities of p53 173L and p53 175P (44), but in order to allow a direct comparison of the transcriptional and cell growth functions of all of the p53 mutants described in this study, we analyzed their activities in both Saos-2 and H358 cells following transient transfection as previously described (44). Analysis of the DNA content of p53-expressing cells by flow cytometry allowed an assessment of both the cell cycle characteristics of the transfected population and an indication of the apoptotic rate provided by the percentage of cells containing sub- $\mathrm{G}_{1}$ amounts of DNA. To avoid including death by necrosis, only normal-size cells with slight losses in DNA content were included. Since these would represent cells at the early stages of apoptosis, the percentage apoptosis measured is a reflection of apoptotic rate rather than total apoptosis. Examples of the flow cytometric analysis of transiently transfected cells are shown in Fig. 5.

Comparison of the percentages of p53-expressing cells in the $\mathrm{G}_{1}$ peak and in the untransfected cell population clearly showed that the p53 mutants fell into two groups with respect to the ability to block cell cycle progression in Saos- 2 cells (Fig. 6). p53 175P and p53 181L were indistinguishable from the wild-type protein in inducing a $\mathrm{G}_{1}$ arrest, consistent with their previously described activities in suppressing the growth of these cells (14). By comparison, p53 173L and p53 22/23 failed to activate a $G_{1}$ arrest, and cells expressing these p53 mutants retained a cell cycle profile similar to that seen in the untransfected cell population. Similar accumulation of cells in the $G_{1}$ population following transfection of wild-type p53, p53 175P, and p53 181L was also seen in H358 cells (data not shown).

Analysis of the induction of cell death in the transfected cells confirmed that both p53 175P and p53173L retain very little apoptotic function in Saos-2 and H358 cells (Fig. 7), although an extremely modest increase in cells containing a sub- $\mathrm{G}_{1}$ DNA content following expression of p53175P for $72 \mathrm{~h}$ (Fig. 7B) supports our previous observation that this mutant may retain some apoptotic function under certain circumstances (44). At these levels of expression, p53 22/23 is also clearly defective for the induction of cell death in Saos-2 and H358 cells (Fig. 7), consistent with the reported activity in transformed rodent cells. These studies also demonstrated a reproducibly lower apoptotic activity for p53181L than for the wildtype protein. Although the p53181L mutant clearly retained some ability to induce cell death, most evident after $72 \mathrm{~h}$ in Saos-2 cells (Fig. 7B), a reduced efficiency was noted in both cell types, supporting the veracity of this reduction in activity. A summary of the activities of the p53 proteins described in this study is shown in Table 1.

Bax expression induces apoptosis in Saos-2 cells. In view of the correlation between lack of activation of the bax promoter and loss of apoptotic activity shown by p53175P, we examined the ability of bax to induce apoptosis directly. Cotransfection of a bax expression plasmid with either CD20 or an inactive p53 mutant as a marker for transfected cells showed that expression of bax alone is sufficient to induce apoptosis in Saos-2 cells (Fig. 8A). Expression of an epitope-tagged Bax protein allowed direct identification of the bax-expressing cells and con- 


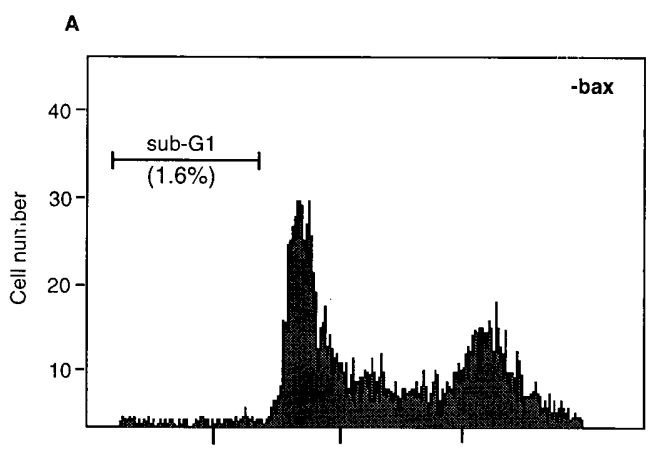

DNAcontent

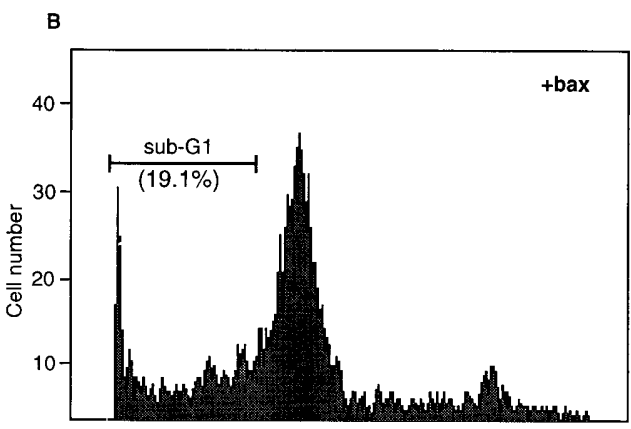

DNAcontent

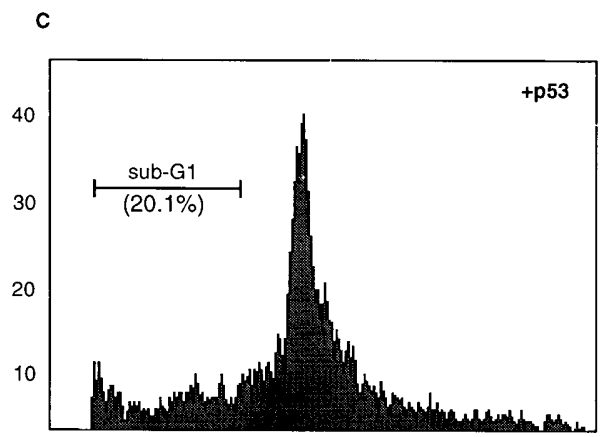

DNAcontent

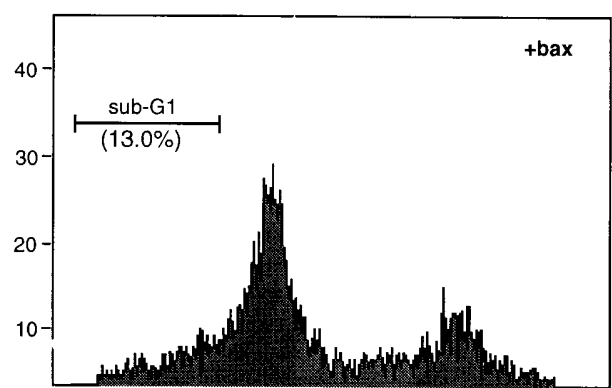

DNAcontent

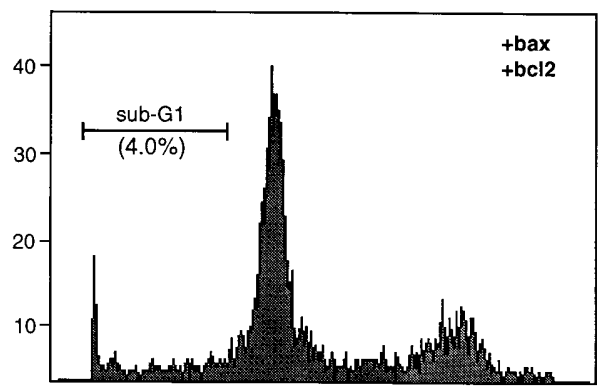

DNAcontent

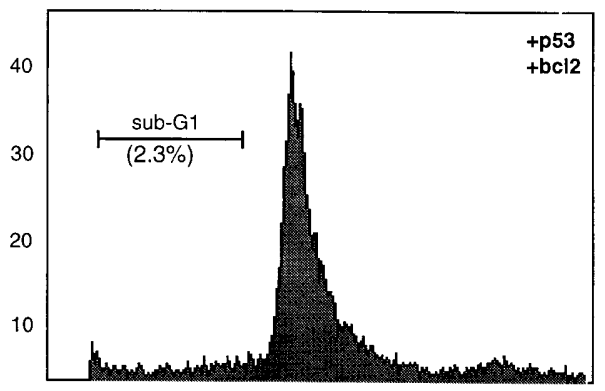

DNAcontent

FIG. 8. Apoptosis in Saos-2 cells expressing bax. (A) Apoptosis in cells expressing the inactive p53 mutant p53 5291 , either with or without bax as indicated. Identical results were obtained when cotransfected CD20 was used to identify transfected cells (data not shown). (B) Apoptosis in cells expressing an epitope-tagged Bax protein, with or without $b c l 2$ as indicated. (C) Apoptosis in cells expressing wild-type p53, with or without $b c l 2$ as indicated.

firmed this apoptotic activity (Fig. 8B). As expected, protection from $b a x$-mediated apoptosis was provided by coexpression of bcl2 (Fig. 8B), which also reduced apoptosis induced by $\mathrm{p} 53$ (Fig. 8C).

\section{DISCUSSION}

Analysis of tumor-derived p53 point mutants has revealed differential specificity in the ability to activate different p53responsive promoters, demonstrating that the retention of wild-type transcriptional activity against some p53 target pro- moters is not necessarily an indication of full wild-type transcriptional potential. The amino acid substitutions carried by these mutants are in the DNA binding domain of $\mathrm{p} 53$, and their transcriptional activities correlated with their abilities to bind DNA containing the p53 binding site present in each of the promoters. Comparison of the transcriptional activities of the p53 mutants with their effects on the cell cycle provides further support for the strong correlation between induction of p21 cip1/waf1 expression and activation of a $\mathrm{G}_{1}$ arrest. This is most clearly demonstrated by p53 $175 \mathrm{P}$, which fails to activate transcription from a number of the target promoters tested yet 
retains the abilities to both induce $\mathrm{p} 21^{\text {cip } 1 / \text { waf } 1}$ expression and activate $\mathrm{G}_{1}$ arrest. Analysis of cells from $\mathrm{p} 21^{\text {cif1/wapl }}$-deficient mice demonstrated a partial loss of the normal p53-induced cell cycle arrest, suggesting that $\mathrm{p} 21^{\text {cifl/wap } 1}$ is a major, but not the sole, mediator of this response $(6,17)$. In human tumor cells, however, abrogation of $\mathrm{p} 21^{\text {cif1/wap } 1}$ expression results in a complete loss of p53-induced cell cycle arrest, supporting a critical role for the activation of $\mathrm{p} 21^{\text {cif } 1 / \text { wap } 1}$ by $\mathrm{p} 53(52)$. It is clear from the results presented here that several potential targets of p53 transcriptional activation, such as the bax and IGF-BP3 promoters, are not likely to play an important role in p53-induced cell cycle arrest, since p53 175P fails to activate transcription from these promoters yet retain the $G_{1}$ arrest function. This is of particular interest in the case of IGF-BP3, a protein which has been shown to inhibit the mitogenic activity of IGF in Saos-2 cells (7). It would appear that this potential block to the proliferative signal is not essential for the arrest of cell cycle progression in these cells.

Most previous studies support a correlation between transcriptional activation by $p 53$ and the induction of a $G_{1}$ arrest, but the dependence of the apoptotic function of p53 on transcriptional activity is more complex. The p53 22/23 mutant failed to activate efficient transcription of any of the tested promoters, as would be expected for a mutation affecting the transactivation, rather than the DNA binding, domain. Loss of apoptotic function for this mutant in Saos-2 cells is consistent with the failure of other transcriptionally inactive mutants to induce apoptosis in these cells (55) and the previously described apoptotic defect of this mutant in transformed rodent cells (45). However, cell death by p53 appears to be a multifaceted process to which transcriptionally dependent and transcriptionally independent mechanisms can contribute, the dependence on each of these functions being a reflection of the environment and type of cell under study. Inhibition of p53 transcriptional activity by $m d m 2$ protects $\mathrm{H} 1299$ but not HeLa cells from p53-induced apoptosis (27), and HeLa cells appear to be primed for death, requiring only the transcriptionally independent function of p53 to activate an apoptotic response. The apoptotic activity shown by p53 22/23 in HeLa cells (29) suggests that this transcriptionally independent apoptotic function remains intact in this mutant and that under appropriate circumstances, this activity alone is sufficient to induce cell death.

The defects in apoptotic activity displayed by p53 175P and p53 181L, which retain at least some transcriptional activity, can be correlated with the specific loss of ability to induce expression from some p53-responsive promoters (Table 1). Similar loss of bax promoter activation is displayed by a temperature-sensitive p53 mutant which activates $\mathrm{p} 21^{\text {cip1/waf } 1}$, but not apoptosis, at the permissive temperature (24). We would therefore like to propose that p53-responsive genes may fall into two groups: those which are instrumental in activating cell cycle arrest and those with a role in mediating apoptosis. A clear candidate for a cell cycle arrest gene is the p21 $1^{\text {cip1/waf1 }}$ gene, although other genes, such as the cyclin G gene, might also play a role. Although bax is an excellent candidate for a p53-induced apoptotic gene, increases in the expression of Bax protein in response to p53 cannot be detected in all cell types, even during the apoptotic response $(2,9,44)$. Taken together with the apparently normal p53-dependent apoptosis seen in bax-deficient thymocytes (35), these observations suggest that bax cannot be the only mediator of p53-dependent apoptosis, and it is of interest that the p53 181L mutant is partially defective for the induction of apoptosis despite showing efficient transactivation of the bax promoter. Nevertheless, we have shown that transient expression of bax can efficiently induce death in Saos-2 cells, supporting at least some role for bax as a p53 apoptotic target. Comparison of the apoptotic activities of the p53 mutants described here with their transcriptional functions in Saos-2 and H358 cells shows a correlation with the activation of the IGF-BP3 promoter. Although inhibition of the mitogenic function of IGF following activation of $I G F-B P 3$ does not appear to be essential for growth arrest, IGF has also been shown to function as an efficient survival factor, protecting cells from p53-dependent, myc-induced apoptosis (26). It is possible that the effect of activation of $I G F-B P 3$ by p53 is to abrogate survival signals, rather than growth signals, thus making the cell more sensitive to other apoptotic functions of p53. Like bax, however, the IGF-BP3 gene is unlikely to be the only apoptotic target of p53.

Finally, it should be pointed out that we have looked at only a small sample of the p53-responsive cellular promoters. Although bax and $I G F-B P 3$ represent attractive candidates for p53-targeted apoptotic genes, it is also possible that our study simply illustrates the principal that differential transcription of critical target genes can favor cell cycle arrest or apoptosis in cells responsive to these function of p53. Modifications of p53 which can regulate DNA binding, such as phosphorylation, or other cellular proteins may also play a role in determining the choice of p53 transcriptional targets and thereby contribute to the final response shown by the cell following p53 activation. In support of such a model, it has been shown that the binding of p53 to various DNA sites is differentially stimulated following phosphorylation by cyclin-dependent kinases (53). Use of mutants such as those described here should greatly facilitate the identification of the true apoptotic targets for p53 transcriptional activation and help reveal the mechanisms by which choice of transcriptional target is normally regulated.

\section{ACKNOWLEDGMENTS}

We thank Moshe Oren and Carol Prives for helpful advice and discussion of unpublished data and Sheldon Rowan for critically reading the manuscript. We are grateful to A. Levine for the $\mathrm{pRc} / \mathrm{CMVhp}$ 5322-23 mutant, B. Vogelstein for the p21 $1^{\text {cip 1/wafl }}$ promoter construct pWWP-luc, J. Reed for the bax promoter sequences, L. Buckbinder for plasmids IGF-BP3 boxALuc and IGF-BP3 (2)boxB-Luc, X. Lu for the anti-p21 $1^{\text {cipl/wafl }}$ antibody SX118, and L. Banks for the anti-p53 antibody PAb1801.

This work was supported by the National Cancer Institute under contract with ABL.

\section{REFERENCES}

1. Abrahamson, J. L. A., J. M. Lee, and A. Bernstein. 1995. Regulation of p53-mediated apoptosis and cell cycle arrest by steel factor. Mol. Cell. Biol. 15:6953-6960.

2. Allday, M. J., G. J. Inman, D. H. Crawford, and P. J. Farrell. 1995. DNA damage in human B cells can induce apoptosis, proceeding from G1/S when p53 is transactivation competent and $\mathrm{G} 2 / \mathrm{M}$ when it is transactivation defective. EMBO J. 14:4994-5005.

3. Baker, S. J., S. Markowitz, E. R. Fearon, J. K. V. Willson, and B. Vogelstein 1990. Suppression of human colorectal carcinoma cell growth by wild-type p53. Science 249:912-915.

4. Banks, L., G. Matlashewski, and L. Crawford. 1986. Isolation of human p53 specific monoclonal antibodies and their use in the studies of human p53 expression. Eur. J. Biochem. 159:529-534.

5. Bates, S., and K. H. Vousden. 1996. p53 in signalling checkpoint arrest or apoptosis. Curr. Opin. Genet. Dev. 6:1-7.

6. Brugarolas, J., C. Chandrasekaran, J. I. Gordon, D. Beach, T. Jacks, and G. J. Hannon. 1995. Radiation-induced cell cycle arrest compromised by p21 deficiency. Nature (London) 377:552-556.

7. Buckbinder, L., R. Talbott, S. Velasco-Miguel, I. Takenaka, B. Faha, B. R. Seizinger, and N. Kley. 1995. Induction of the growth inhibitor IGF-binding protein 3 by p53. Nature (London) 377:646-649.

8. Caelles, C., A. Helmberg, and M. Karin. 1994. p53-dependent apoptosis in the absence of transcriptional activation of p53-target genes. Nature (London) 370:220-223. 
9. Canman, C. E., T. M. Gilmer, S. B. Coutts, and M. B. Kastan. 1995. Growth factor modulation of p53-mediated growth arrest versus apoptosis. Genes Dev. 9:600-611.

10. Chen, J. Y., W. D. Funk, W. E. Wright, J. W. Shay, and J. D. Minna. 1993. Heterogeneity of transcriptional activity of mutant p53 protein and p53 DNA target sequences. Oncogene 8:2159-2166.

11. Collins, M. K. L., J. Marvel, P. Malde, and A. Lopez-Rivas. 1992. Interleukin 3 protects murine bone marrow cells from apoptosis induced by DNA damaging agents. J. Exp. Med. 176:1043-1051.

12. Crook, T., C. Fisher, P. J. Masterson, and K. H. Vousden. 1994. Modulation of transcriptional regulatory properties of p53 by HPV E6. Oncogene 9:1225-1230.

13. Crook, T., R. L. Ludwig, N. J. Marston, D. Willkomm, and K. H. Vousden. 1996. Sensitivity of p53 lysine mutants to ubiquitin-directed degradation trageted by human papillimavirus E6. Virology 217:285-292.

14. Crook, T., N. J. Marston, E. A. Sara, and K. H. Vousden. 1994. Transcriptional activation by p53 correlates with suppression of growth but not transformation. Cell 79:817-827.

15. Crook, T., and K. H. Vousden. 1992. Properties of p53 mutations detected in primary and secondary cervical cancers suggest mechanisms of metastasis and involvement of environmental carcinogens. EMBO J. 11:3935-3940.

16. Demers, G. W., S. A. Foster, C. L. Halbert, and D. A. Galloway. 1994. Growth arrest by induction of p53 in DNA damaged keratinocytes is bypassed by human papillomavirus 16 E7. Proc. Natl. Acad. Sci. USA 91:4382-4386.

17. Deng, C., P. Zhang, J. W. Harper, S. J. Elledge, and P. Leder. 1995. Mice lacking p21 ${ }^{C I P 1 / W A F 1}$ undergo normal development, but are defective in G1 checkpoint control. Cell 82:675-684

18. Diller, L., J. Kassel, C. E. Nelson, M. A. Gryka, G. Ltwak, M. Gebhardt, B. Bressac, M. Ozturk, S. J. Baker, B. Vogelstein, and S. H. Friend. 1990. p53 functions as a cell cycle control protein in osteosarcomas. Mol. Cell. Biol. 10:5772-5781.

19. Donehower, L. A., M. Harvey, B. L. Slagle, M. J. McArthur, C. A. Montgomery, Jr., J. S. Butel, and A. Bradley. 1992. Mice deficient for p53 are developmentally normal but susceptible to spontaneous tumors. Nature (London) 356:215-221.

20. Dulic, V., W. K. Kaufmann, S. J. Wilson, T. D. Tlsty, E. Lees, J. W. Harper S. J. Elledge, and S. I. Reed. 1994. p53-dependent inhibition of cyclindependent kinase activities in human fibroblasts during radiation-induced G1 arrest. Cell 76:1013-1023.

21. El-Deiry, W., T. Tokino, V. E. Velculescu, D. B. Levy, V. E. Parson, J. M. Trent, D. Lin, W. E. Mercer, K. W. Kinzler, and B. Vogelstein. 1993. WAF1, a potential mediator of p53 tumour suppression. Cell 75:817-825.

22. El-Deiry, W. S., S. E. Kern, J. A. Pietenpol, K. W. Kinzler, and B. Vogelstein. 1992. Definition of a consensus binding site for p53. Nat. Genet. 1:45-49.

23. Fredersdorf, S., A. W. Milne, P. A. Hall, and X. Lu. 1996. Immunological analysis of Waf1/Cip1 protein expression in normal human tissues using a panel of novel monoclonal antibodies. Am. J. Pathol. 148:825-835.

24. Friedlander, P., Y. Haupt, C. Prives, and M. Oren. 1996. A mutant p53 that discriminates between p53-responsive genes cannot induce apoptosis. Mol. Cell. Biol. 16:4961-4971.

25. Gottlieb, E., R. Haffner, T. von Ruden, E. F. Wagner, and M. Oren. 1994 Down-regulation of wild-type p53 activity interferes with apoptosis of IL-3 dependent hematopoietic cells following IL-3 withdrawal. EMBO J. 13: $1368-1374$.

26. Harrington, E. A., M. R. Bennett, A. Fanidi, and G. I. Evan. 1994. c-mycinduced apoptosis in fibroblasts is inhibited by specific cytokines. EMBO J. 13:3286-3295.

27. Haupt, Y., Y. Barak, and M. Oren. 1996. Cell type-specific inhibition of p53-mediated apoptosis by mdm2. EMBO J. 15:1596-1606.

28. Haupt, Y., S. Rowan, and M. Oren. 1995. p53-mediated apoptosis in HeLa cells can be overcome by excess pRB. Oncogene 10:1563-1571.

29. Haupt, Y., S. Rowan, E. Shaulian, K. H. Vousden, and M. Oren. 1995. Induction of apoptosis in HeLa cells by trans-activation deficient p53. Genes Dev. 9:2170-2183.

30. Hickman, E. S., S. M. Picksley, and K. H. Vousden. 1994. Cells expressing HPV16 E7 continue cell cycle progression following DNA damage induced p53 activation. Oncogene 9:2177-2181.

31. Hollstein, M., K. Rice, M. S. Greenblatt, T. Soussi, R. Fuchs, T. Sørlie, E. Hovig, B. Smith-Sørensen, R. Montesano, and C. C. Harris. 1994. Database of 53 gene somatic mutations in human tumors and cell lines. Nucleic Acids Res. 22:3551-3555.

32. Hupp, T. R., D. W. Meek, C. A. Midgley, and D. P. Lane. 1992. Regulation of the specific DNA binding function of p53. Cell 71:875-886.

33. Jacks, T., L. Remington, B. O. Williams, E. M. Schmitt, S. Halachmi, R. T. Bronson, and R. A. Weinberg. 1994. Tumour spectrum analysis in p53- mutant mice Curr. Biol. 4:1-7.

34. Katayose, D., R. Wersto, K. H. Cowan, and P. Seth. 1995. Effects of a recombinant adenovirus expressing WAF1/Cip1 on cell growth, cell cycle and apoptosis. Cell Growth Differ 6:1207-1212

35. Knudson, M. C., K. S. K. Tung, W. G. Tourtellotte, G. A. J. Brown, and S. J Korsmeyer. 1995. Bax-deficient mice with lymphoid hyperplasia and male germ cell death. Science 270:96-98.

36. Kobayashi, T., U. Consoli, M. Andreeff, H. Shiku, A. B. Deisseroth, and W. Zhang. 1995. Activation of p21WAF1/Cip1 expression by a temperaturesensitive mutant of human p53 does not lead to apoptosis. Oncogene 11: 2311-2316.

37. Lam, E. W. F., and R. J. Waston. 1993. An E2F-binding site mediates cell-cycle regulation repression of mouse B-myb transcription. EMBO J. 12:2705-2713

38. Lin, J., J. Chen, B. Elenbaas, and A. J. Levine. 1994. Several hydrophobic amino acids in the p53 amino-terminal domain are required for transcriptional activation, binding to $\mathrm{mdm}-2$ and the adenovirus $5 \mathrm{E} 1 \mathrm{~B} 55-\mathrm{kD}$ protein. Genes Dev. 8:1235-1246.

39. Malkin, D., F. P. Li, L. C. Strong, J. F. Fraumeni, Jr., C. E. Nelson, D. H. Kim, J. Kassel, M. A. Gryka, F. Z. Bischoff, M. A. Tainsky, and S. H. Friend. 1990. Germ line p53 mutations in a familial syndrome of breast cancer, sarcomas, and other neoplasias. Science 250:1233-1238.

40. Miyashita, T., S. Krajewski, M. Krajewska, H. G. Wang, H. K. Lin, D. A Liebernmann, B. Hoffman, and J. C. Reed. 1994. Tumor suppressor p53 is a regulator of bcl-2 and bax gene expression in vitro and in vivo. Oncogene 9:1799-1805.

41. Miyashita, T., and J. C. Reed. 1995. Tumor suppressor p53 is a direct transcriptional activator of the human bax gene. Cell 80:293-299.

42. Owen-Schaub, L. B., W. Zhang, J. C. Cusack, L. S. Angelo, S. M. Santee, T. Fujiwara, J. A. Roth, A. B. Deisseroth, W.-W. Zhang, E. Kruzel, and R. Radinsky. 1995. Wild-type human p53 and a temperature-sensitive mutant induce Fas/APO-1 expression. Mol. Cell. Biol. 15:3032-3040.

43. Pietenpol, J. A., T. Tokino, S. Thiagaligam, W. El-Deiry, K. W. Kinzler, and B. Vogelstein. 1994. Sequence-specific transcriptional activation is essential for growth suppression by p53. Proc. Natl. Acad. Sci. USA 91:1998-2002.

44. Rowan, S., R. L. Ludwig, Y. Haupt, S. Bates, X. Lu, M. Oren, and K. H. Vousden. 1996. Specific loss of apoptotic but not cell cycle arrest function in a human tumour derived p53 mutant. EMBO J. 15:827-838.

45. Sabbatini, P., J. Lin, A. J. Levine, and E. White. 1995. Essential role for p53-mediated transcription in E1A-induced apoptosis. Genes Dev. 9:21842192

46. Slebos, R. J. C., M. H. Lee, B. S. Plunkett, T. D. Kessis, B. O. Williams, T. Jacks, L. Hedrick, M. B. Kastan, and K. R. Cho. 1994. p53-dependent G(1) arrest involves pRB-related proteins and is disrupted by the human papillomavirus 16 E7 oncoprotein. Proc. Natl. Acad. Sci. USA 91:5320-5324.

47. Soussi, T., C. Caron de Fromentel, and P. May. 1990. Structural aspects of the p53 protein in relation to gene evolution. Oncogene 5:945-952.

48. Srivastava, S., Z. Zou, K. Pirollo, W. Blattner, and E. H. Chang. 1990 Germ-line transmission of a mutated p53 gene in a cancer-prone family with Li-Fraumeni syndrome. Nature (London) 348:747-749.

49. Thukral, S. K., Y. Lu, G. Chad Blain, T. S. Harvey, and V. L. Jacobsen. 1995. Discrimination of DNA binding sites by mutant p53 proteins. Mol. Cell. Biol. 15:5196-5202.

50. Vojtesek, B., J. Bartek, C. A. Midgley, and D. P. Lane. 1992. An immunochemical analysis of the human nuclear phosphoprotein p53. J. Immunol. Methods 151:237-244.

51. Wagner, A. J., J. M. Kokontis, and N. Hay. 1994. Myc-mediated apoptosis requires wild-type p53 in a manner independent of cell cycle arrest and the ability of p53 to induce p21 waf1/cip1 . Genes Dev. 8:2817-2830.

52. Waldman, T., K. W. Kinzler, and B. Vogelstein. 1995. p21 in necessary for the p53-mediated G1 arrest in human cancer cells. Cancer Res. 55:51875190 .

53. Wang, Y., and C. Prives. 1995. Increased and altered DNA binding of human p53 by S and G2/M but not G1 cyclin-dependent kinases. Nature (London) 376:88-91.

54. Xiong, Y., G. J. Hannon, H. Zhang, D. Casso, R. Kobayashi, and D. Beach. 1993. p21 is a universal inhibitor of cyclin kinases. Nature (London) 366 701-704.

55. Yonish-Rouach, E., V. Deguin, T. Zaitchouk, C. Breugnot, Z. Mishal, J. R. Jenkins, and E. May. 1996. Transcriptional activation plays a role in the induction of apoptosis by transiently transfected wild-type p53. Oncogene 12:2197-2205.

56. Yonish-Rouach, E., D. Resnitzky, J. Lotem, L. Sachs, A. Kimchi, and M Oren. 1991. Wild-type p53 induces apoptosis of myeloid leukaemic cells that is inhibited by interleukin-6. Nature (London) 353:345-347. 